\title{
The Ecosytem Thematic Teaching Using Problem Based Learning Model to Enhance Student's Critical Thinking Skill
}

\author{
Anik Twiningsih \\ Graduate School \\ Sebelas Maret University \\ Surakarta, Indonesia \\ anik.twin@student.uns.ac.id
}

\author{
Sajidan \\ Graduate School \\ Sebelas Maret University \\ Surakarta, Indonesia \\ sajidan@fkip.uns.ac.id
}

\author{
Riyadi \\ Graduate School \\ Sebelas Maret University \\ Surakarta, Indonesia \\ yadi_laras@fkip.uns.ac.id
}

\begin{abstract}
The ecosystem is a lesson that studies the interrelationships between the living and the environment both biotic components and abiotic interplay. Students are required to understand the interaction between living things and life form a unity, order and material characteristics of a complex ecosystem, abstract and difficult to understand, especially for elementary school students. This study aims to 1) how to package the ecosystem material into modules that are easy to understand the student in the learning ecosystem. 2) to improve the skills of critical thinking on the matter ecosystems. Quasi-experimental research methods post-test study design with only non-equivalent control group design. Participants do research at State Primary School Surakarta with sample amounted to 66 students. The sampling technique is cluster random sampling. The collection of data by the method of test and non-test. The results showed that the effect size was large criteria, meaning ecosystem-based modules problembased learning models provide a large positive impact influence on contribution. It can be concluded that an ecosystem can be packaged into modules with the resulting models are thematic learning modules-based ecosystem theme of problem-based learning so easy to understand the student in the learning ecosystem. Implementation of thematic learning modules-based ecosystem theme of problem-based learning can improve students' critical thinking skills in the ecosystem material.
\end{abstract}

Keywords- Thematic Teaching, Problem Based Learning, Critical Thinking Skills

\section{INTRODUCTION}

The 21st Century Education show Indonesian is instructed to national education goals in order to form the 21 st century skills [1]. $21^{\text {st }}$ Century Learning integrated in the curriculum in 2013 which contains 4C is creative thinking skills and problem solving, creativity and innovation, communication and collaboration.

Critical thinking is the ability to be reasonable and reflective with an emphasis on making decisions about what to believe and do [2]. Critical thinking skills as an intellectual discipline process actively and skillfully conceptualizing, applying, analyzing, synthesizing, and / or evaluate the information obtained or generated by observation, experience, reflection, reasoning. Critical thinking skills need to be practiced to students being able to discover the potential of learners in developing their thinking skills [3][5]. Critical thinking skills are very important in expressing your ideas, understanding, viewpoints relevant new information in understanding the various concepts used to analyze and solve problems [6].

Low critical thinking skills of students due to the learning process less develop students' critical thinking skills [7][8]. The learning process to develop and explore every aspect of critical thinking skills Elementary School. Curriculum 2013 learning models emphasize active, creative and innovative. One is the learning model of problem-based learning in teaching learning materials to empower students' critical thinking skill [9].

Learning Problem Based Learning (PBL) is a constructivist approach which emphasizes learning through problem solving experience [10][11]. Problem Based Learning model of learning can design and build students choose a problem in real life and can make the students active in learning [12]. Problem Based Learning (PBL) is a student learning center, students actively participate in solving problems related to the content and context of the investigation [13][15]. Problem Based Learning (PBL) is an independent learning which allows for work group or teamwork for pushing the investigation, collaboration, so that students can develop the skills of students in problem solving and critical thinking skills that can actively construct his own knowledge [16][17].

Ecosystem is learning to learn the interrelationships between the living and the environment both biotic and abiotic components that influence each other. Students are required to understand the interaction between living things and life form a unity, order and material characteristics of a complex ecosystem, abstract and difficult to understand, especially for elementary school students with thematic learning. As a result of this condition which causes the learners to do not understand the concept of ecosystem material. The need for the application of the ecosystem ways of learning materials so that students more easily understand the material. 
Ecosystem is a material that is studying the problems of everyday life [18][19]. Strategies in raises critical a person or group to develop critical thinking skills ecosystem material. So that critical thinking skills are measured through the concept of ecosystem [20][21]. Problems ecosystem orients students on a problem. Students are expected to solve the problems of the ecosystem with learning model of problem-based learning [22][23].

This research was conducted with the purpose of 1) how to package the ecosystem material into modules that are easy to understand elementary school students in thematic learning ecosystem. 2) to improve the skills of critical thinking on the matter ecosystems.

\section{ReSEARCh Methodology}

Research method quasi-experimental research design with post-test only non-equivalent control group design. Participants do research at State Primary School Surakarta with sample amounted to 66 students. Experimental class (using module-based Problem Based student Learning sample size of 33 students) and Existing class (using a school module sample size of 33 students). The sampling technique is cluster random sampling. Instructional material used is a matter of ecosystems. Applied learning model is a model of problem-based learning. The collection of data by nontest methods and test. I.e. non-test data collection questionnaire, observation, interview. Item test questions were developed to measure students' critical thinking skills about the ecosystem material. Validation of the research instrument validation test. Content and construct validity of instruments is done by experts.

\section{RESULTS AND DISCUSSION}

\section{A. Data of the critical thinking skills of students}

Figure 1 shows the result of the measurement data in the form of material test items ecosystem using the model of problem-based learning to improve critical thinking skill.

Image histogram can be seen in Figure 1. It shows a histogram of the results of material data ecosystem using the model of problem-based learning to improve critical thinking skill.

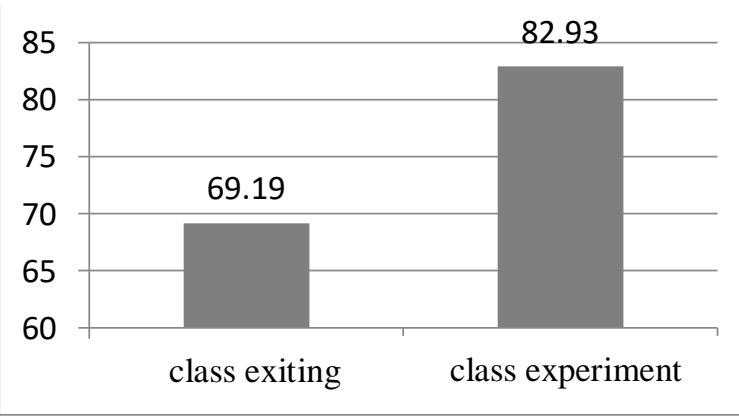

Fig. 1. Histogram results ecosystem material data using a model of problem-based learning to improve critical thinking skills.
Figure 1 can be seen that the results of the data obtained ecosystems average grade students' critical thinking skills existing by $69.19 \%$ while the average critical thinking skills of the experimental class at $82.93 \%$. It can be concluded that an ecosystem can be taught using problem-based learning model of learning. The application of problem-based learning model learning can provide a positive improvement in improving critical thinking skill ecosystem material.

\section{- Prerequisites Test Analysis}

Table 1 shows the analysis prerequisite test consists of normality test data and test results of the pretest equality. Data normality test is to determine whether the data is normal or not normal distribution.

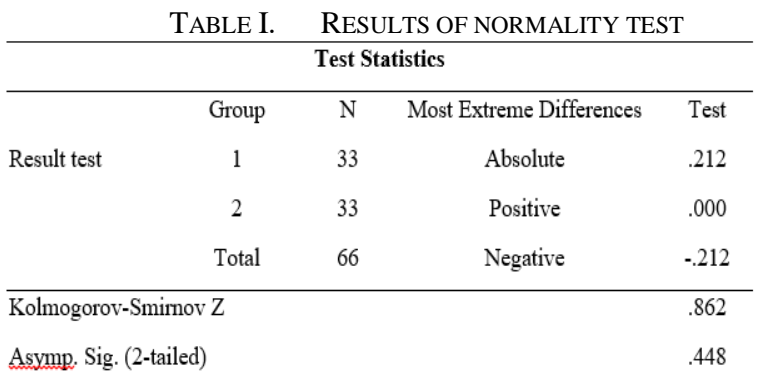

a. Grouping Variable: Group

Table 1 shows that the data normality test results can be described that there are two groups: the experimental group and the control group were respectively numbers 33 students. Test results obtained by the Sig. (2-tailed) $0.448>0.05$, this means that the normal distribution of data.

\section{- Equality test}

Table 2 shows the equivalence test aims to determine the differences between the two groups: an experimental group and a control group. The difference is the result of learning after both groups are given a pretest. Learning outcomes are used to determine the equality of the two groups is the result of studying Middle Semester Exam 2 Academic Year 2016/2017.

\begin{tabular}{|c|c|c|c|c|c|c|}
\hline \multicolumn{7}{|c|}{ Group Statistics } \\
\hline Group & $\mathrm{N}$ & Mean & Std. Deviation & Mean difference & $\mathrm{df}$ & Sig. (2-tailed) \\
\hline 1 & 33 & 71.36 & 7.101 & 3,788 & 64 & 0,075 \\
\hline 2 & 33 & 67.58 & 9.692 & 3,788 & & 0,075 \\
\hline
\end{tabular}

Table 2 shows that tests equality can be described that there are two groups: group 1 (the experimental group) and group 2 (control group) were respectively numbers 33 students. On average the experimental group and the control group 67.5871 .36 with an average difference of 3.788 . Test results obtained by the Sig. (2-tailed) $0.075>0.05$. It can be concluded that the ability of both groups if seen from the results of learning can be said to equal or equivalent. 


\section{- Test Results-T}

Table 3 shows the test of equality aims to determine the differences between the two groups: an experimental group and a control group.

TABLE III. TEST RESULTS OF CRITICAL THINKING SKILLS

\begin{tabular}{cccccccc}
\hline \multicolumn{1}{c}{ Group Statistics } & & & \\
\hline & & & & & & Mean & Sig. \\
Group & N & Mean & T & Df & difference & (2-tailed) \\
Result test Eksperimen PBL & 33 & 82.88 & 3,560 & 64 & 5,394 & 0,001 \\
Exiting & 33 & 77,48 & 3,560 & 63,951 & 5,394 & 0,001 \\
\hline
\end{tabular}

Table 3 Test results of critical thinking skills in table 4:24 can be described that there are two groups: the experimental group and control group were respectively each numbered 33 people. An average of 82.88 experimental class and control class 77.48. Degrees of freedom $(\mathrm{df})=64$ with an average difference of 5.394. The significance value (Sig. 2tailed $)=0.001<0.05$, it means that there are differences in critical thinking skills significant between experimental class and control class. It can be concluded that the products developed can successfully empower students' critical thinking skills.

\section{B. Data calculation of effect size}

Impact the learning effect using thematic modules-based ecosystem theme of Problem Based Learning to empower critical thinking skill School fifth grade students analyzed the effect size using size Rstart Effect Calculator Rstart Effect size Calculator [24]. Table 4 shows the results of calculation of effect size.

TABLE IV. RESULTS OF TEST CALCULATIONS OF EFFECT SIZE

\begin{tabular}{ccccccc}
\hline Class & Mean & \multicolumn{5}{c}{ Effect size } \\
& & & & & & \\
& & Cohen's & Hedges's & Glass's & $\mathbf{r}^{2}$ & Criteria \\
\hline Eksperimen & 82,88 & 0,877 & 0,867 & 0,890 & 0,012 & large \\
Eksiting & 77,48 & & & & & \\
\hline
\end{tabular}

Table 4 shows that the results of the calculation of effect size can be seen the results of effect size cohen's, Hedges's and Glass's criteria is relatively large (large). The impact of the learning effect using thematic modules-based ecosystem theme of the Problem Based Learning contributes co-efficient determination (r2) of 0,012 or $1.2 \%$ in enabling critical thinking skills Elementary School fifth grade students was $98.8 \%$ rest of other factors beyond the use of modules the. It can be concluded that the theme of ecosystem-based thematic modules Problem Based Learning provides a positive impact in empowering influence critical thinking skills Elementary School fifth grade students with the criteria of a relatively large effect size (large).

\section{Discussion pack ecosystem module thematic- based model of problem-based learning}

Ecosystem taught with a model problem-based learning with phases will involve giving the orientation of the issues to students, organizing students to examine, assisting with the investigation independently and groups, develop and present work and exhibiting, analyze and evaluate the process of overcoming the problem [24]. Problem based learning models are applied to accommodate the critical thinking skills of learning activities ecosystems.

Impacts on the first stage of learning problem-based learning begins to divide students into groups of 4-5 people are heterogeneous in each group. Learning ecosystems on the first learning orients students on emerging issues observed by drawing sea water ecosystems and tropical forests. Read discourse ecosystem based 2 components abiotic (producers, consumers, decomposers) and biotic components (soil, water, air, temperature, light). Students discuss autotroph environment or heterotrophic organisms. Figuring out the relationship between abiotic and biotic components [25][26].

Impacts on the second stage of learning problembased learning is the students practice their observation games improve the durability of the heart and lungs with the team running activities in the field. Viewing by forest meadow ecosystems image contained some deer animals and ecosystems rice fields there are two animals buffalo. Read discourse types or kinds of ecosystems. Students discuss the netting food web and constituent biotic and abiotic components in the environment [27].

Impacts on learning the third stage of problembased learning is observing artificial ecosystem that meets human needs, namely rice landed and reservoirs or dams. Read a discourse on human as ecosystem components help each other and work together in exploring natural resources for subsistence. Trying to find the volume of a cube with a unit cube.

Impacts on the fourth stage of the learning problembased learning is observing the traditional ceremony pictures Sekaten Solo. Read a discourse on the role of cultural institutions. Ask important cultural institutions in Indonesia. Finding out about the origins of rhyme. Try to determine the geometrical webs cubes and blocks. Discussing the difference nets cubes and blocks. Solve problems related to the volume of geometrical cubes and blocks.

Impacts on the fifth stage of the learning problembased learning is physical activity the body muscle strength training. Read discourse factors that affect balance ecosystem. Discuss consequences that occur if one of the disturbed balances of the ecosystem.

Impacts on the sixth stage of the learning problembased learning is observing pictures of people who put out the fire. Read discourse about Mapalus to Minahasa. Trying to tell about the importance of cooperation to help each other live in the diversity of the community. Looking out to make life rhyme theme of cooperation.

Understanding of the basic concepts of ecosystems through the process of learning material in teaching ecosystem level thinking skills of students [28][29]. So that students are more interested in learning about the ecosystem material in thematic modules in the learning process. The hope the teacher can facilitate learning and 
provide motivation to learn the material the ecosystem learning model of problem-based learning [30][32].

\section{Discussion improve critical thinking skill}

The learning ecosystem-based thematic Problem Based Learning (PBL) is applied in classroom learning. Teachers can explore the potential of critical thinking skills of students to solve a real problem in the classroom, helping the activity of students in a discussion with a group friend and training students communicate with students more easily find, understand concepts that are difficult [33][34]. This is according to a research study which states that studentcentered learning process that can involve students' active learning in the classroom [35][36]. The teacher gives a problem of learning can create a better learning atmosphere in which these problems can spur a student answers a problem and ways of solving problems in various ways [16][37]. This is in line with Vyotsky learning theory states that social interaction with other friends, triggering the formation of ideas for new ones and to enrich the students' intellectual development [38].

Material Ecosystem-based Problem Based Learning (PBL) through a learning process in the classroom in various ways such as critical reading, writing critically, speak critically, discuss critical to improve the critical thinking skills of students [28][40]. It can train critical thinking skills of students more optimal and facilitates reasoning students as well as solving the problem to explore the statement, questions and answers to critical thinking and the concomitant running of learning activities into student center [41][42].

Ecosystem-based learning in the process of Problem Based Learning (PBL) by involving students with open-ended problems that can enhance students' critical thinking skills for students more opportunities to actively participate, express his ideas in their own way [43][46]. The material in the learning ecosystem by providing open-ended problems that encourage students to familiarize themselves provide evidence of the answers to solving problems that they provide [47][48]. Learners can receive and gather information well in learning to improve their critical thinking skills to discover the ecosystem material [49].

\section{CONCLUSION}

The results of this study concluded that the ecosystem can be packed into thematic modules with a model problem-based learning so that students more easily understand the material in the learning ecosystem. Implementation of thematic learning modules-based ecosystem theme of problem-based learning can improve students' critical thinking skills in the ecosystem material.

\section{ACKNOWLEDGMENT}

The researchers would like to thank all those who have helped learning of teachers and students in Surakarta, Solo.

\section{REFERENCES}

[1] Ennis, R. H. The Nature of Critical Thinking: An Outline of Critical Thinking Dispositions, 2011, pp. 1-8,

[2] Facione, P. a. Critical Thinking : What It Is and Why It Counts. Insight Assessment, (ISBN 13: 978-1-891557-07-1.), 2011, pp. 1-28, http://doi.org/ISBN 13: 978-1-891557-07-1.

[3] Marin, L. M., \& Halpern, D. F. Pedagogy for developing critical thinking in adolescents : Explicit instruction produces greatest gains. Thinking Skills and Creativity, 6(1), 2011, pp. 1-13,. http://doi.org/10.1016/j.tsc.2010.08.002

[4] Butler, H. A., Dwyer, C. P., Hogan, M. J., Franco, A., Rivas, S. F., Saiz, C., \& Almeida, L. S. The Halpern Critical Thinking Assessment and real-world outcomes: Cross-national applications. Thinking Skills and Creativity, 7(2), 2012, pp. 112-121. http://doi.org/10.1016/j.tsc.2012.04.001

[5] Haseli, Z. The Effect of Teaching Critical thinking on Educational Achievement and Test Anxiety among Junior High School Students in Saveh, 2(2), 2013, pp. 168-175,

[6] Peeters, M. J., Zitko, K. L., \& Schmude, K. A. Development of Critical Thinking in Pharmacy Education, 7(1), 2016.

[7] Larsson, K. Understanding and teaching critical thinking-A new approach. International Journal of Educational Research, 84, 2017, pp. 32-42, http://doi.org/10.1016/j.ijer.2017.05.004

[8] Mundilarto, \& Helmiyanto Ismoyo. Effect of Problem-Based Learning on Improvement Physics Achievement and Critical Thinking of Senior High School Student. Journal of Baltic Sience Education, 16(5), 2017, pp. 761-780.

[9] Firdaus, Kailani, I., Bakar, M. N. bin, \& Bakry. Developing Critical Thinking Skills of Students in Mathematics Learning. Journal of Education and Learning, 9(3), 2015, pp. 226-236,

[10] Johnson, M., \& Hayes, M. J. A comparison of problem-based and didactic learning pedagogies on an electronics engineering course. International Journal of Electrical Engineering Education, 53(1), 2016, pp. 3-22, http://doi.org/10.1177/0020720915592012

[11] Ismail, N. S., Harun, J., Aman, M., Megat, Z., \& Salleh, S. The Effect of Mobile Problem-Based Learning Application DicScience PBL on Students' Critical Thinking. Thinking Skills and Creativity, 2018, pp. 1-29, http://doi.org/10.1016/j.tsc.2018.04.002

[12] Sinprakob, S., \& Songkram, N. A proposed model of problembased learning on social media in cooperation with searching technique to enhance critical thinking of undergraduate students. Procedia - Social and Behavioral Sciences, 174, 2015, pp. 2027-2030, http://doi.org/10.1016/j.sbspro.2015.01.871

[13] Wulandari, B., Surjono, H. D., Sudarman, Simone, C. De, Lussier, J., Hall, L., ... I.O'kwu, E. Problem-based learning in teacher education: Trajectories of change Faculty of Education. International Review of Social Sciences and Humanities, 2(1), 2014, pp. 657-662, http://doi.org/0949149X/91

[14] Febriana, B. W., \& Masykuri, M. Effectiveness of Module Based Problem Based Learning (PBL) Toward Student's Achievement Motivation, 2015. ISBN : 978-602-73192-0-2 ISBN : 978-602-73192-0-2, 30-38.

[15] Treadwell, S. M., \& Treadwell, S. M. Making the Case for Project-based Learning (PBL) Physical Education. Jounal of Physical Education, Recreation \& Dance, 3084(89:1), 2018, pp. 5-6, http://doi.org/10.1080/07303084.2018.1393225

[16] Gallagher, S. A., Stepien, W. J., \& Rosenthal, H. The Effects Of Problem Based Learning With Cooperative Learning On Preschoolers' Scientific Creativity Abstract. Journal of Baltic Science Educaiton, 16(1), 2017, pp. 100-113, http://doi.org/10.1177/001698629203600405

[17] Major, T., \& Mulvihill, T. M. Interdisciplinary journal of problem-based learning problem-based learning pedagogies in teacher education: The Case of Botswana. Interdisciplinary Journal of Problem-Based Learning, 12(1), 2018, pp. 1-11, http://doi.org/10.7771/1541-5015.1543

[18] Mosher, H. R., Desrochers, M., Mosher, H. R., \& Desrochers, M. International Journal of Teaching sustainable development 
in higher education Building critical, reflective thinkers through an interdisciplinary approach. International Journal of Sustainability in Higher Education, 2014.

[19] Wilkin, C. L. Enhancing critical thinking: accounting students' perceptions. Education + Training, 59(1), 2017, pp. 15-30, http://doi.org/10.1108/ET-01-2015-0007

[20] Fuad, N. M., Zubaidah, S., Mahanal, S., \& Suarsini, E. Improving Junior High Schools’ Critical Thinking Skills Based on Test Three Different Models of Learning. International Journal of Instruction, 10(1), 2017, pp. 101-116, http://doi.org/10.12973/iji.2017.1017a

[21] Social, I., \& Walker, J. Theoretical Cognitive Principles Observed in the Social Studies Classroom, 6(1), 2016, pp. 143156 ,

[22] Schoenberger-Orgad, M., \& Spiller, D. Critical thinkers and capable practitioners. Journal of Communication Management, 18(3), 2014, pp. 210-221, http://doi.org/10.1108/JCOM-112012-0085

[23] Ulger, K. The Effect of Problem-Based Learning on the Creative Thinking and Critical Thinking Disposition of Students in Visual Arts Education. Interdisciplinary Journal of Problem-Based Learning, 12(1), 2018, pp. 3-6, http://doi.org/10.7771/1541-5015.1649

[24] Sullivan, G. M., \& Feinn, R. Using Effect Size-or Why the $P$ Value Is Not Enough. Journal of Graduate Medical Education, 4(3), 2012, pp. 279-282. http://doi.org/10.4300/JGME-D-1200156.1

[25] Taylor, P., Cochrane, K. L., Augustyn, C. J., Cockcroft, A. C., \& David, J. H. M.. African Journal of Marine Science An ecosystem approach to fisheries in the southern Benguela context, (February 2013), 2010, pp. 37-41.

[26] Zangori, L., \& Forbes, C. T. Exploring Third-Grade Student Model-Based Explanations about Plant Relationships within an Ecosystem Exploring Third-Grade Student Model-Based Explanations about Plant Relationships within an Ecosystem 1, $693 \quad$ (February), 2016. http://doi.org/10.1080/09500693.2015.1118772

[27] Davies, D. J., Earle, S., McMahon, K., Howe, A., \& Collier, C. Development and exemplification of a model for Teacher Assessment in Primary Science. International Journal of Science Education, 39(14), 2017, pp. 1869-1890. http://doi.org/10.1080/09500693.2017.1356942

[28] Fahim, M. Manipulating Critical Thinking Skills in Test Taking, $4(1), \quad 2012, \quad$ pp. 153-160. http://doi.org/10.5296/ije.v4i1.1169

[29] Khasanah, A. N., Widoretno, S., \& Sajidan, S. Effectiveness of Critical Thinking Indicator-Based Module in Empowering Student's Learning Outcome in Respiratory System Study Material. Jurnal Pendidikan IPA Indonesia, 6(1), 2017, pp. 187-195. http://doi.org/10.15294/jpii.v6i1.8490

[30] Kong, L. N., Qin, B., Zhou, Y. qing, Mou, S. yu, \& Gao, H. M. The effectiveness of problem-based learning on development of nursing students' critical thinking: A systematic review and meta-analysis. International Journal of Nursing Studies, 51(3), 2014 , pp. $458-469$. http://doi.org/10.1016/j.ijnurstu.2013.06.009

[31] Fauziah, S., 2elnetthra, F. E., \& 1jedol, DIntegrated ProblemBased Learning Approch In Physics Courses : A Case Study Of Students' Achievement Fauziah, S ., 2 Elnetthra, F . E ., \& 1 Jedol , D . Physics with Electronic Programme, Faculty of Science and Natural Resources Universiti Malaysia Sa. International Journal of Education and Research, 3(8), 2015, pp. 259-270.

[32] Simamora, S. J., Simamora, R. E., \& Sinaga, BApplication of Problem Based Learning to Increase Students ' Problem Solving Ability on Geometry in Class X SMA Negeri 1 Pagaran. International Journal of Sciences: Basic and Applied Research (IJSBAR) ISSN, 4531(36(2)), .2017, pp. 234-251.

[33] Goldstein, L. B., Burke, B. L., Getz, A., \& Kennedy, P. A. Ideas in practice: Collaborative problem-based learning in intermediate algebra. Journal of Developmental Education, 35(1), 2011, pp. 26-37.
[34] Cargas, S., Williams, S., \& Rosenberg, M. An approach to teaching critical thinking across disciplines using performance tasks with a common rubric. Thinking Skills and Creativity, 26, 201, pp. 24-37. http://doi.org/10.1016/j.tsc.2017.05.005

[35] Smith, C. A. Problem-Based Learning Environment In Basic Computer Course: Pre-Service Teachers' Achievement And Key Factors For Learning. Biochemical Education, 25(3(11)), 2015, pp. 205-216. http://doi.org/10.1016/s03074412(97)84433-0

[36] Hamburg, I., \& Vladut, G. PBL - Problem Based Learning for Companies and Clusters. Transportation Research Procedia, 18, 2016, pp. 419-425. http://doi.org/10.1016/j.trpro.2016.12.055

[37] Siew, N. M., \& Mapeala, R. the Effects of Problem-Based Learning With Thinking Maps on Fifth Graders' Science Critical Thinking. Journal of Baltic Science Education, 15(5), 2016, pp. 602-616. Retrieved from http://search.ebscohost.com/login.aspx?direct=true $\& d b=a p h \&$ $\mathrm{AN}=119554063 \&$ site $=$ ehost-live

[38] Zhou, M., \& Brown, D. Educational Learning Theories, 2015, pp. $1-130$.

[39] Chaijaroen, S., Kanjug, I., \& Samat, C. The Study of Learners' Critical Thinking Potential, Learning with Innovation Enhancing Thinking Potential. Procedia - Social and Behavioral Sciences, 46, 2012, pp. 3415-3420. http://doi.org/10.1016/j.sbspro.2012.06.076

[40] Wong, C., Chen, C., \& Osman, K. Cultivating Marginalized Children's Scientific Literacy in Facing the Challenges of the 21st Century, 3(1), 2017, pp. 167-177.

[41] Habimana, O., \& Stambach, A. Kung Fu as critical thinking. Journal of Philosophy in Schools, 2(1), 2015, pp. 56-70.

[42] Ahrari, S., Samah, B. A., Hassan, M. S. H. Bin, Wahat, N. W. A., \& Zaremohzzabieh, Z. Deepening critical thinking skills through civic engagement in Malaysian higher education. Thinking Skills and Creativity, 22, 2016, pp. 121-128. http://doi.org/10.1016/j.tsc.2016.09.009

[43] Jamiah, Y. Internalisasi Nilai-nilai Berpikir Kritis Melalui Pengembangan Model Pembelajaran Konsep Matematika Kreatif pada Pendidikan Anak Usia Dini. Pendidikan Dan Pembelajaran, 19(1), 2012, pp. 229-236.

[44] Nargundkar, S., Samaddar, S., \& Mukhopadhyay, SA guided problem-based learning (PBL) approach: Impact on critical thinking. Decision Sciences Journal of Innovative Education, 12(2), 2014, pp. 91-108. http://doi.org/10.1111/dsji.12030

[45] Nagge, J. J., Killeen, R., \& Jennings, B. Using a course pilot in the development of an online problem-based learning (PBL) therapeutics course in a post-professional PharmD program. Currents in Pharmacy Teaching and Learning, 2017, pp. 1-4. http://doi.org/10.1016/j.cptl.2017.10.005

[46] Ku, K. Y. L., Lee, V. S. L., \& Ellis, J. W. Using artwork as problem context in generic critical thinking instruction: A strategy for thoughts. Thinking Skills and Creativity, 25, 2017, pp. 53-59. http://doi.org/10.1016/j.tsc.2017.07.001

[47] Mudrikah, A. www.ijres.net Problem-Based Learning Associated by Action-Process-Object-Schema (APOS) Theory to Enhance Students' High Order Mathematical Thinking Ability Problem-Based Learning Associated by ActionProcess-Object-Schema (APOS) Theory to Enhance Students. International Journal of Research in Education and Science (IJRES) International Journal of Research in Education and Science, 2(1), 2016, pp. 125-135.

[48] Rosdiana, Gina Cahya, Tjutju Yuniarsih, Gina Cahya, I. W. I. Towards Students ' Critical Thinking Skills Moderated By Self. International Journal of Educational Research, 2(3), 2018, 15-26.

[49] Bahmani, S. Improved critical thinking in students using current events journaling. International Journal of Sociology and Social Policy, 36(3/4), 2016, pp. 190-202. http://doi.org/10.1108/IJSSP-04-2015-0038 